\title{
Impact of season of harvest on in vitro gas production and dry matter degradability of Acacia saligna leaves with inoculum from three ruminant species
}

\author{
Abdel-Fattah Z.M. Salem* \\ Department of Animal Production, Faculty of Agriculture (El-Shatby), \\ Alexandria University, Alexandria, Egypt
}

\begin{abstract}
In vitro gas production (IVGP) and dry matter degradability (IVDMD) of Acacia saligna leaves (ASL) from four seasons were studied under arid Egyptian conditions as a $4 \times 3$ factorial experiment ( 4 seasons $\times 3$ ruminant species). Incubations were completed using rumen liquid collected immediately after slaughter from sheep, cattle and buffalo, in order to investigate differences among ruminants in their ASL fermentation capacity. Samples of ASL were collected during the last 2 months of each season, being autumn, winter, spring and summer (between the 5th and 12th week of each season). Dried samples of ASL were incubated for $24 \mathrm{~h}$ in each of the three buffered rumen liquors, using a syringe technique, to determine IVGP and IVDMD. The crude protein content of ASL was lower $(P<0.01)$ in summer $(143 \mathrm{~g} / \mathrm{kg} \mathrm{DM})$ than autumn $(171 \mathrm{~g} / \mathrm{kg} \mathrm{DM})$, winter $(177 \mathrm{~g} / \mathrm{kg} \mathrm{DM})$ and spring $(182 \mathrm{~g} / \mathrm{kg} \mathrm{DM})$. In winter, ASL had lower neutral detergent fibre, acid detergent fibre, acid detergent lignin and cellulose than in other seasons $(P<0.05)$, but there were no differences among seasons in ash and hemicellulose contents. Condensed tannin (CT, as quebracho tannin equivalent) contents of ASL were higher $(P<0.001)$ in summer $(113 \mathrm{~g} / \mathrm{kg} \mathrm{DM})$ versus the other seasons, with the lowest value during winter $(63 \mathrm{~g} / \mathrm{kg} \mathrm{DM})$. Gas production after $24 \mathrm{~h}$ was higher $(P<0.05)$ with buffalo rumen fluid, versus cattle or sheep, in all seasons except winter. IVGP with buffalo rumen fluid was not affected by season but, with cattle and sheep, IVGP was higher $(P<0.01)$ in winter. IVDMD was higher in winter
\end{abstract}

Abbreviations: ADF, acid detergent fibre; ADL, acid detergent lignin; CEL, cellulose; CP, crude protein; CT, condensed tannins; DM, dry matter; GY, gas yield; HCEL, hemicellulose; IVDMD, in vitro DM degradability; IVGP, in vitro gas production; NDF, neutral detergent fibre; RGP, rate of gas production

* Corresponding author. Tel.: +203 5292727; fax: +203 5901900.

E-mail address: asalem70@yahoo.com. 
and spring, and lower in summer and autumn, within all species, and higher $(P<0.001)$ values were general with buffalo versus other species. IVGP was positively $(P<0.05)$ correlated with IVDMD, but there was no consistent relationship between IVGP or IVDMD and chemical composition of ASL. Rumen fluid from buffalo, cattle and sheep have different capacities to ferment $A$. saligna leaves, and differences among species were smallest in winter, when the fibre and CT contents of ASL were lower. (c) 2005 Elsevier B.V. All rights reserved.

Keywords: Seasonal variation; Acacia saligna; Condensed tannins; Gas production; Dry matter degradability; Buffalo; Cattle; Sheep

\section{Introduction}

Browse species play a major role as feeds for ruminants in arid and semi-arid regions, particularly during the dry season when poor quality forage and crop residues are common (Ahn et al., 1989; Kibon and Ørskov, 1993). During these dry periods, forage trees remain green and maintain a relatively high crude protein (CP) content (D'Mello, 1992), and their foliage is commonly used as a protein and energy supplement to ruminants fed low quality forages (Reed et al., 1990). However, legume trees and shrubs contain a wider range of secondary compounds than conventional fodders (D'Mello, 1992). Thus, although they may contain adequate concentrations of nutrients, the presence of these compounds could present constraints to their use as feed supplements (Dzowela et al., 1987).

Many browse species are associated with deleterious effects on livestock performance either due to toxic and/or secondary compounds that can reduce feed intake and nutrient utilization. Salem et al. (2004) detected phenolic compounds, saponins, alkaloids and lectins, which can be highly toxic to ruminal and intestinal bacteria, in Acacia saligna leaves (ASL). However the primary secondary compound in Acacia species, and many other browse species, appears to be condensed tannins (CT), which are widely distributed in leaves of trees and shrubs (D'Mello, 1992), but occur in leaves and stems of only a small number of specialized non-woody forage legume plants (Barry, 1989).

Little information is available on effects of seasonal variation on the nutritive value of A. saligna leaves to different ruminant species. The objective was to investigate impacts of season on chemical composition, in vitro gas production and dry matter (DM) degradability of A. saligna leaves using rumen fluid from three ruminant species under the arid conditions of north Egypt.

\section{Materials and methods}

\subsection{Collection of A. saligna leaves}

Leaves were collected from the experimental station of the Faculty of Agriculture (Alexandria University, Alexandria, Egypt) over all seasons, being autumn (from September to November), winter (from December to February), spring (from March to May) and summer (from June to August) of 2003. Leaves were collected each week for 8 weeks 
starting from the 5 th week and ending in the 12 th week of each season. A. saligna leaves were randomly and manually harvested from different parts of both young and mature leaves from different trees within and around the experimental station. On each week, a representative sample was collected from the same site (i.e., three samples each week). As ASL was collected in the last 8 weeks of each season, the total number of leaf samples was 32 ( 8 weeks $\times 4$ seasons). Weekly samples were mixed, dried at $40^{\circ} \mathrm{C}$ and stored. The DM content of each week's samples was determined in triplicate by placing samples in an oven at $40^{\circ} \mathrm{C}$ to constant weight. Dried samples were ground in a hammer mill to pass a $1 \mathrm{~mm}$ sieve and stored in plastic bags for subsequent determination of chemical components, CT, and in vitro characterisation using rumen fluid from buffalo, cattle and sheep.

\subsection{Chemical composition and condensed tannins}

Procedures described by AOAC (1980) were used to determine ash and Kjeldahl N. Neutral detergent fiber (NDF), acid detergent fiber (ADF) and acid detergent lignin (ADL) were determined according to methods of Goering and Van Soest (1970). Cellulose (CEL) and hemicellulose (HCEL) contents were calculated from the difference between ADF and ADL and between NDF and ADF, respectively.

The CT were determined by Porter et al. (1986) with the modification of Makkar (2000) using butanol/HCl. Butanol/ $\mathrm{HCl}(95: 5, \mathrm{v} / \mathrm{v})$ and ferric ammonium sulphate $(20 \mathrm{~g} / \mathrm{l} 2 \mathrm{M}$ $\mathrm{HCl})$ were used as reagents, and a solution of purified quebracho tannin $(1 \mathrm{mg} / \mathrm{ml}$ aqueous acetone, $700 \mathrm{ml} / \mathrm{l}$ ) was the standard. Absorbance was measured against a blank at $550 \mathrm{~nm}$.

\subsection{In vitro gas production (IVGP) and in vitro dry matter degradability (IVDMD)}

The IVGP was determined according to Menke et al. (1979) with the modification of Salem et al. (2000). Two hundred milligrams of each sample (in triplicate) was placed in a $60 \mathrm{ml}$ syringe. The piston of each syringe was lubricated with vaseline to prevent inflow of water to the syringe during incubation. Rumen fluid was collected from the rumen of the three ruminant species, that were all fed a restricted amount (about $15 \mathrm{~g} / \mathrm{kg}$ of live weight) of a commercial concentrate mixture (120-140 g/ $\mathrm{kg}$ crude protein) and wheat straw ad libitum. Immediately after slaughter, which occurred on different days, of four adult female or male animals (Egyptian buffaloes about 400-450 kg; hybrid cattle (Friesian $\times$ Egyptian cattle) about $350-400 \mathrm{~kg}$, and Barki sheep about 40-45 kg) selected on the basis of their live weights and ages to minimize variation in rumen inoculum, samples of fresh digesta were collected from the rumen of each animal. All 32 ASL samples were incubated with rumen fluid from each species in four runs per species, and mixed rumen fluid from the four animals was used in each run. The samples of ASL leaves were incubated in triplicate with each species rumen fluid and repeated in four separate runs. Four blank samples were included per run. The total number of animals used in each ruminant species was 16 (4 runs $\times 4$ animals/run) and incubations were completed during June, July and August of 2004.

In each run, rumen digesta was squeezed through four layers of cheesecloth to ensure liquor contained microbial populations from both the liquid and solid phases. Rumen liquor of each ruminant species was homogenized and kept at approximately $39^{\circ} \mathrm{C}$ in a water bath, 
flushed with $\mathrm{CO}_{2}$ before use, and diluted (1:4 v:v) with the culture medium of Makkar et al. (1995), and FAO/IAEA (2000), containing bicarbonate buffer, macro-mineral, micromineral, resazurine and reducing solution. Buffered rumen fluid $(25 \mathrm{ml})$ was pipetted into each syringe and syringes were immediately placed in a water bath at $39^{\circ} \mathrm{C}$. Gas volumes were recorded at 2, 4, 6, 10, 12 and $24 \mathrm{~h}$ of incubation.

At the end of the incubation (i.e., $24 \mathrm{~h}$ ), contents of each syringe were transferred to centrifuge tubes and centrifuged at $20,000 \times g$ for $20 \mathrm{~min}$ at $4{ }^{\circ} \mathrm{C}$. The residual pellet was lyophilized in the tubes overnight. The residual moisture, if any, was removed by drying the tubes overnight at $60^{\circ} \mathrm{C}$, and then tubes were weighed and IVDMD calculated from differences between initial and residue weights, minus blank tubes.

\subsection{Calculations and statistical analysis}

Total gas production (IVGP) and IVDMD at $24 \mathrm{~h}$ were determined, and rate of gas production at 4, 6 and $11 \mathrm{~h}$ (RGP) was calculated from recorded volumes of gas produced before and after these times. For example, RGP at $4 \mathrm{~h}$ was calculated as:

$$
\begin{aligned}
& \mathrm{RGP}_{4 \mathrm{~h}}(\mathrm{ml} / \mathrm{g} \mathrm{DM} / \mathrm{h}) \\
& \quad=\frac{(\text { volume of gas produced at } 6 \mathrm{~h}-\text { volume of gas produced at } 2 \mathrm{~h})}{4 \times \text { sample weight }(\mathrm{g})}
\end{aligned}
$$

Gas yields $\left(\mathrm{GY}_{24 \mathrm{~h}}\right)$ were calculated as the volume of gas produced after $24 \mathrm{~h}$ of incubation divided by the amount of substrate apparently degraded.

IVGP, RGP, GY and IVDMD were analysed as a $4 \times 3$ factorial experiment ( 4 seasons $\times 3$ ruminant species) using the general linear model of SAS (1999) with methods of Steel and Torrie (1980). Differences among seasons, species and the season $\times$ species interaction used Duncan's multiple-range test (Duncan, 1955).

Pearson correlation coefficients between IVGP, RGP, GY and IVDMD of the ruminant species in the different seasons were estimated using SAS (1999) and the correlation between IVGP, GY, IVDMD and the CT content of the ASL leaves was also estimated for each ruminant species in each season.

\section{Results and discussion}

\subsection{Chemical composition}

There were no differences between growth seasons in ash and HCEL contents of ASL (Table 1). The CP content was lower $(P<0.01)$ in summer $(143 \mathrm{~g} / \mathrm{kg} \mathrm{DM})$ versus autumn $(171 \mathrm{~g} / \mathrm{kg} \mathrm{DM})$, winter $(177 \mathrm{~g} / \mathrm{kg} \mathrm{DM})$ and spring (182 g/kg DM). In winter, ASL had lower $(P<0.05) \mathrm{NDF}, \mathrm{ADF}, \mathrm{ADL}$ and CEL contents than in spring, and intermediate values were observed in autumn and summer. Poor chemical composition of A. saligna can be a major factor limiting its use as a supplementary feed for ruminants (Degen et al., 1997). In the current study, large differences in the nutritive value of Acacia leaves (as assessed by gas production and DM degradability) were observed, which were primarily the result of changes in maturity. 
Table 1

Chemical composition and condensed tannins (g/kg DM) contents of Acacia saligna leaves harvested each week during the second and third month of each season

\begin{tabular}{|c|c|c|c|c|c|c|}
\hline \multirow[t]{2}{*}{ Item } & \multicolumn{4}{|c|}{ Season (mean of 8 weeks, $n=24$ ) } & \multirow[t]{2}{*}{ Sed } & \multirow[t]{2}{*}{$P$-value } \\
\hline & Autumn & Winter & Spring & Summer & & \\
\hline Ash & 73.9 & 74.3 & 80.5 & 85.1 & 7.04 & 0.737 \\
\hline $\mathrm{CP}$ & $171^{\mathrm{a}}$ & $177^{\mathrm{a}}$ & $182^{\mathrm{a}}$ & $143^{\mathrm{b}}$ & 11.9 & 0.013 \\
\hline NDF & $353^{\mathrm{ab}}$ & $332^{\mathrm{b}}$ & $374^{\mathrm{a}}$ & $356^{\mathrm{ab}}$ & 13.8 & 0.041 \\
\hline $\mathrm{ADF}$ & $274^{\mathrm{ab}}$ & $258^{\mathrm{b}}$ & $298^{\mathrm{a}}$ & $276^{\mathrm{ab}}$ & 13.7 & 0.043 \\
\hline ADL & $143^{\mathrm{ab}}$ & $133^{\mathrm{b}}$ & $154^{\mathrm{a}}$ & $142^{\mathrm{ab}}$ & 8.0 & 0.044 \\
\hline CEL & $131^{\mathrm{ab}}$ & $125^{\mathrm{b}}$ & $145^{\mathrm{a}}$ & $135^{\mathrm{ab}}$ & 8.7 & 0.039 \\
\hline HCEL & 79.4 & 74.1 & 75.9 & 79.5 & 2.71 & 0.147 \\
\hline $\mathrm{CT}$ & $77.1^{\mathrm{b}}$ & $62.6^{\mathrm{b}}$ & $79.5^{\mathrm{b}}$ & $113^{\mathrm{a}}$ & 9.40 & $<0.0001$ \\
\hline
\end{tabular}

$\mathrm{CP}$, crude protein; NDF, neutral detergent fiber; ADF, acid detergent fiber; ADL, acid detergent lignin; CEL, cellulose; HCEL, hemicellulose; CT, condensed tannins (as quebracho tannins equivalent). Means in the same row with different superscripts ( $\mathrm{a}$ and $\mathrm{b})$ differ $(P<0.05)$.

Reduction $(P<0.01)$ in the CP content of ASL in summer versus other seasons, is consistent with other studies, as was the observation that the minimum CP content of fodder tree leaves in the dry season was more than twice that of grasses in the wet season (Skarpe and Bergstrom, 1986; Evitayani et al., 2004). However, the CP content of ASL remained relatively high $(143 \mathrm{~g} / \mathrm{kg} \mathrm{DM})$ in the dry season, suggesting the possibility that Acacia sp. leaves may be used as a dry season fodder and/or as a feed supplement to low quality diets. However, secondary compounds in Acacia species may prevent its use in this way, if the nutrients cannot be digested and utilized.

Mean values of CT were higher $(P<0.001)$ in summer $(113 \mathrm{~g} / \mathrm{kg} \mathrm{DM})$ versus other seasons, with the lowest value in winter $(63 \mathrm{~g} / \mathrm{kg} \mathrm{DM})$. This agrees with results of Cabiddu et al. (2000), who reported CT contents of various browse species. It could reflect effects of high summer temperatures on concentrations of tannins, which may change as the plant matures due to physiological changes. Decreased concentrations of CT of Acacia leaves in winter may be due to the plant allocating more soluble carbohydrates to growth and reproduction, rather than to producing tannins, which have high metabolic costs of production (Skogsmyr and Fagerstrom, 1992). This may also explain the reduced $(P<0.05)$ concentration of fibre fractions in winter. Soil type, fertility and water supply affect tannin concentrations in plants. Moreover, seasonal variations in response to climatic and physiological changes in browse plants induce changes in chemical composition and, in particular, in concentrations of secondary compounds such as tannins (Dann and Low, 1988). These differences determine the value of browse plant foliage as forage resources for ruminants.

However, several factors affect both levels and solubility of CT in leaves. The amount of CT in foliage may vary with genotype (Baldwin et al., 1987), CT levels and extractability change during the growing season (Hagerman, 1988), and the content of CT in tree and shrub foliage can vary with age of the plant and age of the foliage. Degen et al. (1997) found that although foliage from older A. saligna trees had higher total CT content, it was only half the level in foliage from young trees. Makkar et al. (1991) found that CT increased with 
maturity of leaves in a number of oak species. In our study, such effects were not evident, probably because ASL samples consisted of a mixture of young and mature leaves.

\subsection{In vitro gas production and dry matter degradability}

The total volume of gas produced (IVGP) and IVDMD estimated from in vitro fermentation of ASL in each season are in Table 2, rates of gas production at 4, 6 and $11 \mathrm{~h}$ (RGP, $\mathrm{ml}$ gas/g DM/h) and gas yields (GY, ml gas/g DMD) are in Table 3, and cumulative gas production profiles of ASL fermented with rumen inoculum of ruminant species during each season are in the Fig. 1 . Gas production after $24 \mathrm{~h}$ was higher $(P<0.05)$ with buffalo rumen fluid versus cattle or sheep in every season except winter. There were interactions $(P<0.001)$ between season and species, as IVGP was not affected by season within buffalo rumen fluid, but in cattle and sheep it was higher $(P<0.01)$ in winter. With sheep, IVGP was also lower $(P<0.01)$ in summer versus spring and autumn. There was also an interaction $(P<0.001)$ between season and species for IVDMD. As with IVGP, IVDMD was higher with buffalo rumen liquid versus other species and, in all species, it was higher in winter and spring versus summer and autumn $(P<0.001)$. However, differences between buffalo and cattle and sheep were higher in winter, spring and summer versus autumn.

Interactions also occurred among species and seasons in rates of gas production to 4 $(P=0.009)$ and $6 \mathrm{~h}(P=0.042)$. To $4 \mathrm{~h}$, cattle and sheep had higher rates of gas production in winter versus other seasons, whereas there was no effect of season within buffalo. Rate of gas production was higher with buffalo versus cattle or sheep. To $6 \mathrm{~h}$, rate of gas production was higher in spring with buffalo and cattle than it was in autumn and winter but, with sheep, the highest rate of gas production was in summer, while this was the season associated with the

Table 2

In vitro gas production (IVGP, $\mathrm{ml}$ gas/2000 $\mathrm{mg} \mathrm{DM}$ ) and in vitro dry matter degradability (IVDMD, g/kg) after $24 \mathrm{~h}$ of incubation of Acacia saligna leaves (harvested each week during the second and third month of each season) with rumen liquor from buffalo, cattle and sheep

\begin{tabular}{|c|c|c|c|c|c|c|}
\hline \multirow[t]{2}{*}{ Animal } & \multicolumn{4}{|c|}{ Season (mean of 8 weeks, $n=24$ ) } & \multirow[t]{2}{*}{ Sed } & \multirow[t]{2}{*}{$P$-value } \\
\hline & Autumn & Winter & Spring & Summer & & \\
\hline \multicolumn{7}{|l|}{ IVGP } \\
\hline Buffalo & $309^{\mathrm{a}}$ & 325 & $319^{\mathrm{a}}$ & $318^{\mathrm{a}}$ & 11.8 & 0.607 \\
\hline Cattle & $288^{\mathrm{bB}}$ & $320^{\mathrm{A}}$ & $290^{\mathrm{bB}}$ & $282^{\mathrm{bB}}$ & 11.5 & 0.013 \\
\hline Sheep & $285^{\mathrm{bB}}$ & $315^{\mathrm{A}}$ & $285^{\mathrm{bB}}$ & $265^{\mathrm{cC}}$ & 3.2 & $<0.0001$ \\
\hline Sed & 10.1 & 6.4 & 6.3 & 6.6 & $7.9^{\S}$ & $0.001^{\S}$ \\
\hline$P$-value & 0.043 & 0.279 & $<0.0001$ & $<0.0001$ & & \\
\hline \multicolumn{7}{|l|}{ IVDMD } \\
\hline Buffalo & $334^{\mathrm{B}}$ & $428^{\mathrm{A}}$ & $424^{\mathrm{aA}}$ & $357^{\mathrm{aB}}$ & 15.8 & $<0.0001$ \\
\hline Cattle & $314^{\mathrm{B}}$ & $398^{\mathrm{A}}$ & $387^{\mathrm{bA}}$ & $317^{\mathrm{bB}}$ & 16.9 & $<0.0001$ \\
\hline Sheep & $301^{\mathrm{B}}$ & $392^{\mathrm{A}}$ & $380^{\mathrm{bA}}$ & $299^{\mathrm{bB}}$ & 14.4 & $<0.0001$ \\
\hline Sed & 19.2 & 27.2 & 14.0 & 10.7 & $12.1^{\S}$ & $0.0001^{\S}$ \\
\hline$P$-value & 0.253 & 0.092 & 0.01 & $<0.0001$ & & \\
\hline
\end{tabular}

Means in the same row with different superscripts $(\mathrm{A}-\mathrm{C})$ differ $(P<0.05)$ between seasons within species. Means in the same column with different superscripts (a and c) differ $(P<0.05)$ between species within season.

$\S$ Sed and $P$-value of the interaction between species and season. 

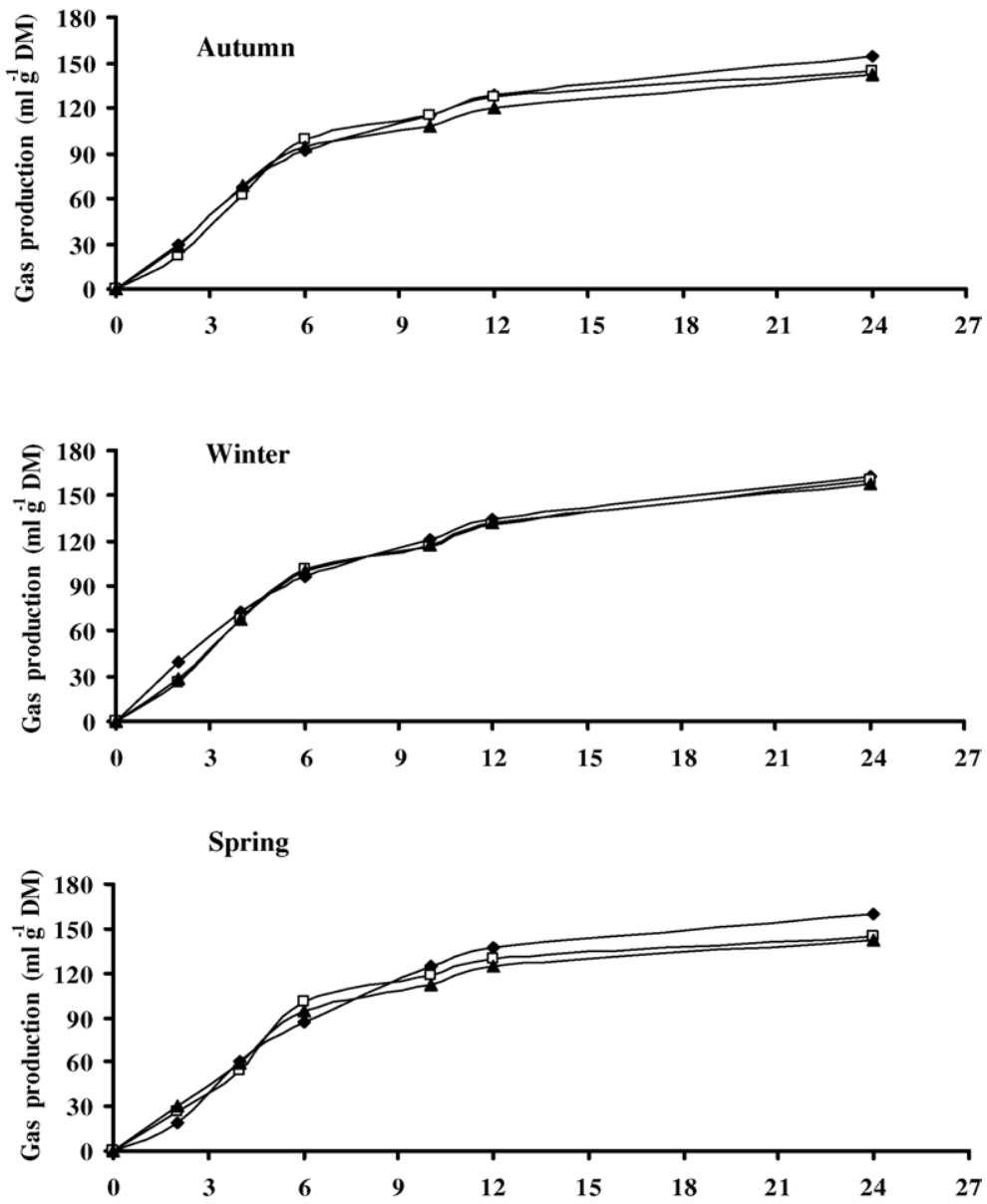

Summer

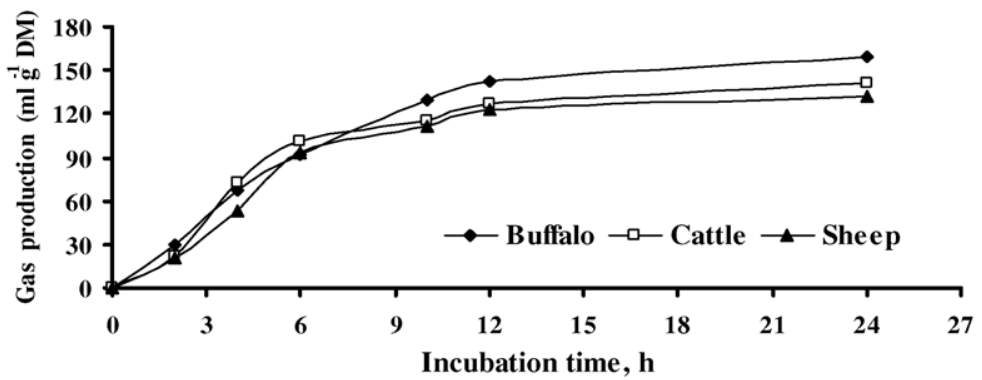

Fig. 1. Cumulative gas production profiles ( $\mathrm{ml}$ gas/g DM) from in vitro fermentation of buffalo, cattle and sheep rumen digesta for different growing seasons of Acacia saligna leaves. (Values of 8 weeks $\times 3$ samples of each species within each season.) 
Table 3

Rate of gas production (RGP, ml gas/g DM/h at 4, 6 and $11 \mathrm{~h}$ ) and gas yield (GY, ml gas/g DM disappeared) of Acacia saligna leaves harvested each week during the second and third month of each season, with rumen liquor of buffalo, cattle and sheep

\begin{tabular}{|c|c|c|c|c|c|c|}
\hline \multirow[t]{2}{*}{ Animal } & \multicolumn{4}{|c|}{ Season (mean values of eight weeks, $n=24$ ) } & \multirow[t]{2}{*}{ Sed } & \multirow[t]{2}{*}{$P$-value } \\
\hline & Autumn & Winter & Spring & Summer & & \\
\hline \multicolumn{7}{|l|}{ RGP $4 \mathrm{~h}$} \\
\hline Buffalo & $19.5^{\mathrm{a}}$ & 19.4 & $17.9^{\mathrm{a}}$ & $18.5^{\mathrm{a}}$ & 0.99 & 0.096 \\
\hline Cattle & $17.4^{\mathrm{bB}}$ & $18.5^{\mathrm{A}}$ & $16.8^{\mathrm{bB}}$ & $17.5^{\mathrm{abB}}$ & 0.46 & 0.020 \\
\hline Sheep & $16.6^{\mathrm{bB}}$ & $18.0^{\mathrm{A}}$ & $16.0^{\mathrm{bB}}$ & $16.1^{\mathrm{bB}}$ & 0.53 & $<0.0001$ \\
\hline Sed & 0.95 & 0.63 & 0.37 & 0.95 & $0.70^{\S}$ & $0.009^{\S}$ \\
\hline$P$-value & 0.002 & 0.083 & $<0.0001$ & 0.002 & & \\
\hline \multicolumn{7}{|l|}{ RGP $6 \mathrm{~h}$} \\
\hline Buffalo & $12.0^{\mathrm{aB}}$ & $12.0^{\mathrm{B}}$ & $15.9^{\mathrm{aA}}$ & $15.5^{\mathrm{aA}}$ & 0.26 & $<0.0001$ \\
\hline Cattle & $12.9^{\mathrm{aB}}$ & $12.1^{\mathrm{B}}$ & $15.9^{\mathrm{aA}}$ & $10.6^{\mathrm{bC}}$ & 0.52 & $<0.0001$ \\
\hline Sheep & $10.0^{\mathrm{bD}}$ & $12.4^{\mathrm{C}}$ & $13.3^{\mathrm{bB}}$ & $14.9^{\mathrm{aA}}$ & 0.12 & $<0.0001$ \\
\hline Sed & 0.66 & 0.24 & 0.33 & 0.32 & $0.35^{\S}$ & $0.042^{\S}$ \\
\hline$P$-value & 0.001 & 0.291 & $<0.0001$ & $<0.0001$ & & \\
\hline \multicolumn{7}{|l|}{ RGP $11 \mathrm{~h}$} \\
\hline Buffalo & $6.63^{\mathrm{B}}$ & $7.23^{\mathrm{A}}$ & $6.45^{\mathrm{aB}}$ & $6.25^{\mathrm{aB}}$ & 0.247 & 0.003 \\
\hline Cattle & $6.23^{B}$ & $7.00^{\mathrm{A}}$ & $6.03^{\mathrm{bB}}$ & $5.70^{\mathrm{bB}}$ & 0.248 & 0.0001 \\
\hline Sheep & $6.28^{\mathrm{B}}$ & $6.99^{\mathrm{A}}$ & $5.95^{\mathrm{bC}}$ & $5.48^{\mathrm{bD}}$ & 0.069 & $<0.0001$ \\
\hline Sed & 0.341 & 0.140 & 0.130 & 0.130 & $0.187^{\S}$ & $0.092^{\S}$ \\
\hline$P$-value & 0.453 & 0.189 & 0.002 & $<0.0001$ & & \\
\hline \multicolumn{7}{|l|}{ GY } \\
\hline Buffalo & $464^{\mathrm{A}}$ & $383^{\mathrm{B}}$ & $377^{\mathrm{B}}$ & $446^{\mathrm{B}}$ & 18.0 & $<0.0001$ \\
\hline Cattle & $460^{\mathrm{A}}$ & $405^{\mathrm{B}}$ & $376^{\mathrm{B}}$ & $446^{\mathrm{A}}$ & 16.4 & $<0.0001$ \\
\hline Sheep & $478^{\mathrm{A}}$ & $406^{\mathrm{B}}$ & $377^{\mathrm{B}}$ & $442^{\mathrm{A}}$ & 18.6 & $<0.0001$ \\
\hline Sed & 12.1 & 19.2 & 14.0 & 15.7 & $14.5^{\S}$ & $0.0041^{\S}$ \\
\hline$P$-value & 0.699 & 0.458 & 1.000 & 1.000 & & \\
\hline
\end{tabular}

Means in the same row with different superscripts (A-D) different $(P<0.05)$. Means in the same column with different superscripts ( $\mathrm{a}$ and $\mathrm{b})$ different $(P<0.05)$.

$\S$ Sed and $P$-value of the interaction between species and season.

lowest rate of gas production in cattle. Buffalo and cattle had higher rates of gas production than sheep in spring and autumn, but there was no difference among species in winter and, in summer, it was buffalo and sheep that had higher rates of gas production. To $11 \mathrm{~h}$, the highest rate of gas production was in spring with all species. Differences among species were confined to spring and summer, when buffalo had a higher rate of gas production than both cattle and sheep. Results might reflect differences in fermentation capacity of rumen fluid from buffaloes vs. cattle and sheep fed the same diet (Calabro and Willimas, 1998; Calabro et al., 2000). Ruminal bacteria in buffaloes had a higher capacity to degrade tannic acid versus cattle and sheep (Salem and Gohar, 2004). Van Soest, (1994) found a higher amount of degraded organic matter and microbial growth with buffalo rumen fluid compared to that of cows. Our IVDMD had highest values in winter and spring and decreased $(P<0.001)$ from summer to autumn. 
There was no effect of species on gas yield in any season. Gas yield is a measure of fermentability of degraded substrate, and so the lack of a species effect indicates that there was no difference among species in partitioning of degraded substrate to fermentation endproducts versus microbial growth. However, there was an effect of season on gas yield, and an interaction $(P=0.004)$ between species and season. Higher gas yields occurred in autumn and summer, versus winter and spring, with a small increase in variation among species in winter. The winter and spring ASL samples had a numerically higher CP content than did those in autumn and summer, and this may be partly why degraded material in winter and spring was not associated with gas production, as protein is not extensively fermented and ammonia produced from its fermentation reduces estimated gas volume produced (Cone and Van Gelder, 2000).

Our observations are similar to Evitayani et al. (2004), who found that IVGP and IVDMD of some legume species increased in the wet season (winter) compared with the dry season (summer). The effect of season on gas production for cattle and sheep, and in DM degradability for all species could be due to effects of CT on available $\mathrm{N}$ in leaves which, in summer, had a highly negative effect resulting in low rumen ammonia concentrations (Bonsi et al., 1995), which then reduced microbial growth. Conversely, Acacia leaves in winter were more degradable (and fermentable - resulting in higher gas production), and this was associated with a lower $(P<0.001)$ CT content (Table 1$)$ compared with dry summer season. Kakengi et al. (2005) also reported that tannins in browse leaves negatively affected gas production.

The IVGP in buffalo was not related to the chemical composition of ASL, but the rumen fluid from cattle and sheep showed a negative relationship between IVGP and CT content (Table 4). The relationship between IVDMD and chemical composition was less clear, but rumen fluid from sheep again had a slightly negative relationship between IVDMD and CT content. Rate of gas production to $4 \mathrm{~h}$ was not well related to the chemical composition of

Table 4

Correlation coefficients between in vitro and chemical composition data of Acacia saligna leaves harvested throughout the year

\begin{tabular}{|c|c|c|c|c|c|c|}
\hline \multirow[t]{2}{*}{ Item } & \multicolumn{2}{|c|}{ Condensed tannins } & \multicolumn{2}{|c|}{ Crude protein } & \multicolumn{2}{|c|}{ Neutral detergent fibre } \\
\hline & Coefficient & $P$-value & Coefficient & $P$-value & Coefficient & $P$-value \\
\hline IVGP, buffalo & -0.221 & 0.7270 & 0.146 & 0.4290 & -0.367 & 0.5558 \\
\hline IVGP, cattle & -0.773 & 0.2627 & 0.516 & 0.0094 & -0.762 & 0.8617 \\
\hline IVGP, sheep & -0.920 & 0.0001 & 0.712 & 0.0203 & -0.655 & 0.0362 \\
\hline IVDMD, buffalo & -0.512 & 0.0273 & 0.596 & 0.1078 & -0.069 & 0.4252 \\
\hline IVDMD, cattle & -0.660 & 0.0146 & 0.712 & 0.0171 & -0.149 & 0.6414 \\
\hline IVDMD, sheep & -0.690 & 0.0027 & 0.741 & 0.0560 & -0.484 & 0.2695 \\
\hline Gas yield, buffalo & 0.493 & 0.0189 & 0.346 & 0.2075 & 0.193 & 0.2900 \\
\hline Gas yield, cattle & -0.639 & 0.0331 & -0.581 & 0.2715 & 0.072 & 0.6941 \\
\hline Gas yield, sheep & -0.068 & 0.1343 & -0.286 & 0.2245 & 0.052 & 0.7794 \\
\hline RGP 4 h, buffalo & 0.160 & 0.3804 & 0.193 & 0.2889 & 0.427 & 0.0148 \\
\hline RGP $4 \mathrm{~h}$, cattle & -0.287 & 0.1110 & 0.205 & 0.2614 & 0.294 & 0.1686 \\
\hline RGP $4 \mathrm{~h}$, sheep & 0.195 & 0.2839 & -0.2997 & 0.0957 & -0.418 & 0.0172 \\
\hline
\end{tabular}

IVGP, in vitro gas production; IVDMD, in vitro dry matter degradability; RGP, rate of gas production at $4 \mathrm{~h}(\mathrm{ml} / \mathrm{g}$ $\mathrm{DM} / \mathrm{h}$ ). 
Table 5

Correlations between in vitro data produced by taking rumen fluid from different species of anima

\begin{tabular}{|c|c|c|c|c|c|c|c|c|c|c|c|}
\hline \multirow[t]{2}{*}{ Item } & \multicolumn{3}{|l|}{ IVGP } & \multicolumn{3}{|l|}{ IVDMD } & \multicolumn{3}{|l|}{ Gas yield } & \multicolumn{2}{|l|}{ RGP $4 \mathrm{~h}$} \\
\hline & Buffalo & Cattle & Sheep & Buffalo & Cattle & Sheep & Buffalo & Cattle & Sheep & Buffalo & Cattle \\
\hline IVGP, cattle & $0.692^{* * * *}$ & & & & & & & & & & \\
\hline IVDMD, buffalo & $0.851^{\mathrm{ns}}$ & $0.661^{*}$ & $0.628^{* *}$ & & & & & & & & \\
\hline IVDMD, cattle & $0.792^{*}$ & $0.744^{* * *}$ & $0.745^{\mathrm{ns}}$ & $0.983^{* * *}$ & & & & & & & \\
\hline IVDMD, sheep & $0.767^{\mathrm{ns}}$ & $0.749^{* *}$ & $0.761^{* * *}$ & $0.975^{* * *}$ & $0.999^{* * *}$ & & & & & & \\
\hline Gas yield, buffalo & $-0.779^{\mathrm{ns}}$ & $-0.566^{\mathrm{ns}}$ & $-0.560^{* *}$ & $-0.989^{* *}$ & $-0.970^{*}$ & $-0.963^{*}$ & & & & & \\
\hline Gas Yield, cattle & $-0.690^{*}$ & $-0.366^{\mathrm{ns}}$ & $-0.370^{\mathrm{ns}}$ & $-0.936^{*}$ & $-0.891^{* * *}$ & $-0.883^{\mathrm{ns}}$ & $0.974^{* * *}$ & & & & \\
\hline Gas yield, sheep & $-0.757^{\mathrm{ns}}$ & $-0.370^{\mathrm{ns}}$ & $-0.339^{\mathrm{ns}}$ & $-0.941^{*}$ & $-0.880^{\mathrm{ns}}$ & $-0.866^{\mathrm{ns}}$ & $0.968^{* * *}$ & $0.992^{* * *}$ & & & \\
\hline RGP 4 h, buffalo & $0.687^{* * *}$ & $0.160^{\mathrm{ns}}$ & $-0.256^{\mathrm{ns}}$ & $0.160^{\mathrm{ns}}$ & $0.045^{\mathrm{ns}}$ & $-0.182^{\mathrm{ns}}$ & $0.203^{\mathrm{ns}}$ & $0.059^{\mathrm{ns}}$ & $0.118^{\mathrm{ns}}$ & & \\
\hline RGP $4 \mathrm{~h}$, cattle & $0.505^{* *}$ & $0.662^{* * *}$ & $-0.168^{\mathrm{ns}}$ & $-0.004^{\mathrm{ns}}$ & $0.153^{\mathrm{ns}}$ & $-0.335^{\mathrm{ns}}$ & $0.275^{\mathrm{ns}}$ & $0.296^{\mathrm{ns}}$ & $303^{*}$ & $0.477^{* * *}$ & \\
\hline RGP $4 \mathrm{~h}$, sheep & $0.147^{\mathrm{ns}}$ & $0.235^{\mathrm{ns}}$ & $0.189^{* *}$ & $-0.020^{\mathrm{ns}}$ & $-0.043^{\mathrm{ns}}$ & $-0.098^{\mathrm{ns}}$ & $0.088^{\mathrm{ns}}$ & $0.219^{\text {ns }}$ & $0.193^{\text {ns }}$ & $-0.479^{* * *}$ & $0.088^{\mathrm{ns}}$ \\
\hline
\end{tabular}

IVGP, in vitro gas production; IVDMD, In vitro dry matter degradability; RGP, rate of gas production at $4 \mathrm{~h}$ (ml/g DM/h); ns, not significant.

$P<0.05$.

** $P<0.01$.

*** $P<0.001$. 
ASL for any species, which agrees with the extensively reported suppressive effect of CT on rumen degradation, and on the interference of these compounds with microbial attachment to feeds (McLeod, 1974; McAllister et al., 1994; Aharoni et al., 1998; Getachew et al., 2000; Rubanza et al., 2003; Osuga et al., 2005). Results are also consistent with Frutos et al. (2002), who observed a negative correlation between CT and IVGP in sheep with different leguminous shrubs. The study by Evitayani et al. (2004) also found that the nutritive value of legume, as assessed by nutrient digestibility and metabolizable energy content, was higher in the rainy versus the dry season. The CT not bound to protein can inhibit fermentation of structural carbohydrates in the rumen by forming indigestible complexes with cell wall carbohydrates, rendering them undegradable. It can also form complexes with microbial enzymes, rendering them inactive (Gamble et al., 1996), which could reduce IVGP. Khazaal et al., (1992) reported that microbial gas production and in vivo DM disappearance decreased with increased concentrations of extractable polyphenolics in browse species. However, our results suggest that microbial populations in buffalo rumen fluid are less sensitive to effects of tannins than are those in rumen fluid from cattle and sheep. This species difference may be important when feeding the species, but it also suggests that gas production data using rumen fluid from sheep or cattle may not be related to gas production from buffalo rumen fluid.

The IVGP and IVDMD were positively correlated (Table 5), but negatively related to gas yield. Relationships between IVDMD and gas yield from the three species were generally well related to each other, but estimates of IVGP and RGP had a poor relationship between buffalo and sheep and, to a lesser extent, between buffalo and cattle. The relationship between cattle and sheep was good for IVGP, but very poor for RGP. Data suggest that sheep may be suitable donors of rumen fluid when feeds are being characterized for extent, but not rate, of degradation in cows, but they are not suitable models for buffalo.

\section{Conclusions}

Degradability and fermentability of A. saligna leaves was affected by season for cattle and sheep, but not for buffalo, with reductions of in vitro gas production in the dry summer leaves. This may partly explain why animals avoid $A$. saligna leaves when foraging, especially late in the growing season. Buffalo rumen fluid inoculum had a higher ability to tolerate negative effects associated with increased concentrations of secondary components. While it may be possible to use sheep as models for cattle to characterize tanniniferous feeds (such as ASL), in vitro, it appears that neither cattle nor sheep rumen inoculum can be used as a model for buffaloes.

\section{Acknowledgements}

The author thanks Dr. M.Z.M. Salem (Department of Timber Trees and Wood Technology) at the same university for his helpful in providing the collection of A. saligna leaves during the four seasons. Also, thanks to Dr. Y.M. Gohar (Division of Microbiology, Faculty of Science), for helpful comments and revision of the manuscript. I gratefully acknowledge 


\section{Dr. Caroline Rymer (Animal Science Research Group, University of Reading, UK) for assistance and advice during revision of the manuscript.}

\section{References}

Aharoni, Y., Gilboa, N., Silanikove, N., 1998. Models of suppressive effect of tannins: analysis of the suppressive effect of tannins on ruminal degradation by compartmental models. Anim. Feed Sci. Technol. 71, $251-267$.

Ahn, J.H., Robertson, B.M., Elliot, R., Gutteridge, R.C., 1989. Quality assessment of tropical browse legumes: tannin content and protein degradation. Anim. Feed Sci. Technol. 27, 147-156.

A.O.A.C., 1980. Official Methods for Analysis, 13th ed. Washington, DC, USA.

Baldwin, I.T., Schultz, J.C., Ward, D., 1987. Patterns and sources of leaf tannin variation in yellow birch (Betula allegheniensis) and sugar maple (Acer saccharum). J. Chem. Ecol. 13, 1069-1078.

Barry, T.N., 1989. Condensed tannins: their role in ruminant protein and carbohydrate digestion and possible effects upon the rumen ecosystem. In: Nolan, J.V., Leng, R.A., Demeyer, D.I. (Eds.), The Roles of Protozoa and Fungi in Ruminant Digestion. Penambul Books, Armidale, NSW, Australia, pp. 153-169.

Bonsi, M.L., Osuji, P.O., Tuah, A.K., 1995. Effect of supplementing teff straw with different level of Lucaena or Sesbania leaves on the degradabilities of teff straw, Sesbania Tagasate and Vernonia and on certain rumen and blood metabolites in Ethiopian Menz sheep. Anim. Feed Sci. Technol. 52, 101-129.

Cabiddu, A., Decandia, M., Sitiza, M., Molle, G., 2000. A note on the chemical composition and tannin content of some Mediterranean shrubs browsed by Sarda goats. OPTIONS Méditerranéennes 52, 175-178.

Calabro, S., Infascelli, F., Bovaera, F., Piccolo, V., 2000. Comparison of fermentation characteristics of rumen fluid from buffalo and sheep using an automated pressure evaluation system. In: Gas Production: Fermentation Kinetics for Feed Evaluation and to Assess Microbial Activity. An EAAP Satellite Symposium, British Society of Animal Science and Wageningen University, Wageningen, The Netherlands, p. 103.

Calabro, S., Willimas, B.A., 1998. Differences between fermentative ability of rumen fluid from buffalo and dairy cows to measure cumulative gas production. In Vitro Technique for Measuring Nutrient Supply to Ruminants, Occ. Publ. No. 22, BSAS, pp. 195-198.

Cone, J.W., Van Gelder, A.H., 2000. Influence of protein fermentation on gas production. In: Gas Production: Fermentation Kinetics for Feed Evaluation and to Assess Microbial Activity. An EAAP Satellite Symposium, British Society of Animal Science and Wageningen University, Wageningen, The Netherlands, pp. 23-24.

Dann, R.R., Low, S., 1988. Assessing the value of browse plants as alternative sources of fodder. Agric. Sci. 1, 20-27.

Degen, A.A., Blanke, A., Becker, K., Kam, M., Benjamin, R.W., Makkar, H.P.S., 1997. The nutritive value of Acacia saligna and Acacia salicina for goats and sheep. Anim. Sci. 64, 253-259.

D'Mello, J.P.F., 1992. Chemical constraints to the use of tropical legumes in animal nutrition. Anim. Feed Sci. Technol. 38, 237-261.

Duncan, D.B., 1955. Multiple ranges and multiple $F$-test. Biometrics 11, 1-42.

Dzowela, B.H., Hove, L., Maasdorp, B.V., Mafongoya, P.L., 1987. Recent work on the establishment, production and utilization of multipurpose trees as a feed resource in Zimbabwe. Anim. Feed Sci. Technol. 69, 1-15.

Evitayani, Warly, L., Fariani, A., Ichinohe, T., Abdulrazak, S.A., Fujihara, T., 2004. Comparative rumen degradability of some legumes forages between wet and dry seasons in west Sumatra, Indonesia. Asian-Aust. J. Anim. Sci. 17, 1107-1111.

FAO/IAEA, 2000. Quantification of Tannins in Tree Foliage, FAO/IAEA, Rome, Italy.

Frutos, P., Hervas, G., Ramos, G., Giradles, F.J., Mantecon, A.R., 2002. Condensed tannin content of several shrub species from a mountain area in northern Spain, and its relationship to various indicators of nutritive value. Anim. Feed Sci. Technol. 95, 215-226.

Gamble, G.G., Akin, D.E., Makkar, H.P.S., Becker, K., 1996. Biological degradation of tannins in Sericea lespedeza (lespedeza cuneata) by the white rot fungi Ceriporiopsis subvermispora and Cyathus stercoreus analyzed by solid-state ${ }^{13} \mathrm{C}$ nuclear magnetic resonance spectroscopy. Appl. Environ. Microbiol. 62, 3600-3604.

Getachew, G., Makkar, H.P.S., Becker, K., 2000. Effect of polyethylene glycol on in vitro degradability of nitrogen and microbial protein synthesis from tannin-rich browse and herbaceous legumes. Br. J. Nutr. 84, 73-83. 
Goering, H.K., Van Soest, P.J., 1970. Forage fiber analysis (apparatus reagents, procedures and some applications). In: Agricultural Handbook. Agricultural Research Service, United States Department of Agriculture, Washington, DC, USA, p. 379.

Hagerman, A.E., 1988. Extraction of tannin from fresh and preserved leaves. J. Chem. Ecol. 14, 453-461.

Kakengi, A.M.V., Shem, M.N., Sarwatt, S.V., Fujihara, T., 2005. Can Moringa oleifera be used as a protein supplement for ruminant? Asian-Aust. J. Anim. Sci. 18, 42-47.

Khazaal, K., Markantonatons, X., Nastis, A., Ørskov, E.R., 1992. Changes with maturity in fibre composition and levels of extractable polyphenols in Greek browse: effects on in vitro gas production and in sacco dry matter degradation. J. Sci. Food Agric. 63, 237-244.

Kibon, A., Ørskov, E.R., 1993. The use of degradation characteristics of browse plants to predict intake and digestibility by goats. Anim. Prod. 57, 247-251.

Makkar, H.P.S., 2000. Quantification of Tannins in Tree Foliage, A Laboratory Manual. FAO/IAEA, Vienna, Austria.

Makkar, H.P.S., Bluemmel, M., Becker, K., 1995. Formation of complexes between polyvinyl pyrrolidones or polyethylene glycols and tannins, and their implication in gas production and true digestibility in vitro techniques. Br. J. Nutr. 73, 897-913.

Makkar, H.P.S., Dawra, R.K., Singh, B., 1991. Tannin levels in leaves of some oak species at different stages of maturity. J. Sci. Food Agric. 54, 513-519.

McAllister, T.A., Bae, H.D., Jones, G.A., Cheng, K.J., 1994. Microbial attachment and feed digestion in the rumen. J. Anim. Sci. 72, 3004-3018.

McLeod, N.M., 1974. Plant tannins - their role in forage quality. Nutr. Abst. Rev. 44, 803-815.

Menke, K.H., Raab, L., Salewski, A., Steingass, H., Fritz, D., Schneider, W., 1979. The estimation of the digestibility and metabolisable energy content of ruminant feedingstuffs from the gas production when they are incubated with rumen liquor in vitro. J. Agric. Sci. 93, 217-222.

Osuga, I.M., Abdulrazak, S.A., Ichinohe, T., Fujihara, T., 2005. chemical composition, degradation characteristics and effect of tannin on digestibility of some browse species from Kenya havasted during the wet season. Asian-Aust. J. Anim. Sci. 18, 54-60.

Porter, L.J., Hrstich, L.N., Chan, B.G., 1986. The conversion of proanthocyanidins and prodelphinidins to cyanidin and delphinidin. Phytochemistry 25, 223-230.

Reed, J.D., Soller, H., Woodward, A., 1990. Fodder tree and straw diets for sheep: intake, growth, digestibility and the effects of phenolics on nitrogen utilization. Anim. Feed Sci. Technol. 30, 39-50.

Rubanza, C.D.K., Shem, M.N., Otsyina, R., Ichinohe, T., Fujihara, T., 2003. Nutritive evaluation of some browse tree legume foliages native to semi-arid area in western Tanzania. Asian-Aust. J. Anim. Sci. 16, 1429-1437.

Salem, A.Z.M., Gohar, Y.M., 2004. Anaerobic ruminal bacterial isolates from the rumen of different ruminant animals and their response to different levels of tannic acid. In: Habe, F. (Ed.), 55th Annual Meeting of the EAAP, p. 265.

Salem, A.Z.M., Gohar, Y.M., El-Adawy, M.M., Salem, M.Z.M., 2004. Growth-inhibitory effect of some antinutritional factors extracted from Acacia saligna leaves on intestinal bacteria activity in sheep. In: The 12th Scientific Conference of the Egyptian Society of Animal Production (ESAP), vol. 41, pp. 283-300.

Salem, A.Z.M., Gonzalez, J.S., Lopez, S., Ranilla, M.J., 2000. Short- and long-term effects of feeding quebracho treated hay on the fermentation activity of the rumen liquid of sheep. In: Gas Production: Fermentation Kinetics for Feed Evaluation and to Assess Microbial Activity. An EAAP Satellite Symposium, British Society of Animal Science and Wageningen University, Wageningen, The Netherlands, p. 86.

SAS, 1999. SAS Companion for Microsoft Windows, Version 6, SAS Institute Inc., Cary, NC, USA.

Skarpe, C., Bergstrom, R., 1986. Nutrient content and digestibility of forage plants in relation to plant phonology and rainfall in the Kalari, Botswana. J. Arid Environ. 11, 147-164.

Skogsmyr, I., Fagerstrom, T., 1992. The cost of anti-herbivory defense: an evaluation of some ecological and physiological factors. Okios 64, 451-457.

Steel, R.G.D., Torrie, J.H., 1980. Principles and Procedures of Statistics, second ed. McGraw-Hill International, New York, NY, USA.

Van Soest, P.J., 1994. Nutritional Ecology of the Ruminant. Cornell University Press, Ithaca, NY, USA. 